\title{
Penerapan Teknologi Pembuatan Kompos Bagi Kelompok Petani Kopi Arabika di Kelurahan Kisanata
}

\author{
Verdy A Koehuan*, Matheus M Dwinanto, Dominggus G H Adoe, \\ Kristomus Boimau \\ Fakultas Sains dan Teknik, Universitas Nusa Cendana \\ email: verdy.koehuan@staf,undana.ac.id
}

\begin{abstract}
The Community Empowerment Program of Kisanata Village, Bajawa Sub-district in utilizing agricultural waste such as leaves, wood branches, and grass with a composition of $30 \%$ green and $60 \%$ brown and $10 \%$ other components for making compost. The main target of this program is the people of Kisanata village and its surroundings, especially the Flores Bajawa Arabica coffee farmers. In this activity, it is hoped that the community will be able to understand and be skilled at making fertilizers from forage and bokashi which are economically valuable from agricultural waste materials. This is certainly very helpful for the farming community in increasing agricultural productivity as well as their welfare. The purpose of this activity is to increase the role of the community in preserving the environment as an ecological service and of economic value. The method applied in this activity includes an action research perspective with the benefits to be achieved, namely improvement and increased understanding of the compost-making process. The result of the activity is increasing the knowledge and skills of farmers in the process of organic fertilizers from agricultural waste that is widely available in the surrounding environment
\end{abstract}

Keywords: Program Kemitraan Masyarakat, Hydram Pumps, Training, and Maintenance

\begin{abstract}
Abstrak
Program Pemberdayaan Masyarakat kelurahan Kisanata, kecamatan Bajawa dalam memanfaatkan limbah pertanian seperti daun-daun, ranting-ranting kayu, dan rumput dengan komposisi 30\% hijauan dan $60 \%$ bahan coklat serta $10 \%$ komponen lain untuk pembuatan pupuk kompos. Sasaran utama program ini adalah petani kopi Arabika Flores Bajawa. Pada kegiatan ini diharapkan masyarakat tersebut dapat memahami dan terampil membuat pupuk dari hijauan dan bokashi yang bernilai ekonomis dari bahan limbah pertanian. Hal ini tentu sangat membantu petani dalam meningkatkan produktifitas pertanian sekaligus kesejahteraan mereka. Tujuan dari kegiatan ini yaitu untuk meningkatkan peran masyarakat dalam melestarikan lingkungan hidup sebagai jasa ekologi dan bernilai ekonomi. Metode yang diterapkan dalam kegiatan ini yaitu mencakup pada perspektif action research dengan manfaat yang ingin dicapai yakni perbaikan dan peningkatan pemahaman terhadap proses pembuatan pupuk kompos. Hasil kegiatan yaitu meningkatkan pengetahuan dan keterampilan petani dalam proses pupuk organik dari limbah pertanian yang banyak terdapat di lingkungan sekitarnya.
\end{abstract}

Kata Kunci: Pupuk Kompos, Pupuk Hijau, Bokashi, Kopi Arabika Organik dan Limbah Pertanian

\section{PENDAHULUAN}

Kebutuhan masyarakat akan pupuk setiap tahun meningkat sehingga permintaan pasar juga turutmeningkat. Pemanfaatan pupuk sintetik bertujuan menaikankan produksi tanaman, karena sangat efektif, dimana hasilnya cepat, dan 
tidak susah dalam mengaplikasikannya, serta mudah didapat. Namun penggunaan pupuk sintetik ini menjadi serba salah, selain sangat dibutuhkan oleh petani dalam tanaman mereka, tapi jika secara terus menerus digunakan maka akan sangat merusak struktur tanah, menurunkan kesuburan tanah dan kualitas lingkungan lainnya[1][2]. Selain itu, petani harus mengeluarkan biaya ekstra untuk membeli pupuk sintetik. Untuk memperkecil dampak penggunaan pupuk sintetik adalah dengan memanfaatkan berbagai jenis tumbuhan yang menghasilkan senyawasenyawa berpotensi sebagai pupuk kompos ataupun bokashi (pupuk organik nabati) untuk mengembalikan kualitas

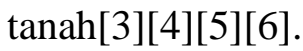

Kabupaten Ngada, provinsi Nusa Tenggara Timur sejak tahun 2017 telah mencanangkan kesepakatan untuk melaksanakan Pertanian ramah lingkungan dengan visi menuju Kabupaten Ngada yang Go Organik. Dalam menjalankan Visi ini Pemerintah memiliki 3 (tiga) konsep pertanian ramah lingkungan, yakni: Go Clean, Go Green dan Go Organik. Sebelum menghasilkan produk organik perlu melakukan upaya Go Clean dan Go Green, Pemerintah juga berupaya menetapkan kawasan yang diharapkan dapat menghasilkan produk pangan yang organik. Untuk itu dari aspek budidaya sangatlah penting menggunakan sarana produksi yang organik salah satu diantaranya adalah penyediaan pupuk organik lokal dan pestisida nabati lokal.

Dalam upaya ini Pemerintah Kabupaten Ngada telah melakukan fasilitasi terhadap kelompok penghasil pupuk organik yang diharapkan dapat mensuplai pupuk organik lokal ke para petani. Langkah ini juga merupakan upaya yang dilakukan Pemerintah untuk melakukan pemberdayaan kepada kelompok pengelola pupuk organik. Dalam upaya menghasilkan pupuk organik lokal Pemerintah melalui Dinas Pertanian Kabupaten Ngada terus melakukan pembinaan dan pengawasan terhadap kelompok penyedia pupuk organik lokal. Untuk itu sebagai upaya agar tersedianya produk pangan dan hortikultura yang aman bagi kesehatan maka Pemerintah Kabupaten Ngada mengalokasikan dana melalui DPA Dinas Pertanian Kabupaten Ngada Tahun Anggaran 2019 program diversifikasi tanaman dialokasikan sejumlah anggaran untuk menyediakan pupuk organik lokal dan pestisida nabati lokal yang kesemuanya itu dihasilkan di Kabupaten Ngada.

Salah satu kabupaten penghasil kopi di Propinsi Nusa Tenggara Timur adalah Kabupaten Ngada yang dikenal dengan kopi Arabika Flores Bajawa (AFB). Saat ini luasan tanaman kopi arabika di Kabupaten Ngada Tahun 2019 seluas 7170 Ha yang melibatkan 9.000 KK di 3 Kecamatan yaitu Kecamatan Bajawa, Golewa dan Golewa Barat. dengan Total Produksi 3.459 ton (kopi beras). Selama kurun waktu tahun 2011 sampai tahun 2019, produktifitas kopi cenderung meningkatkecualitahun 2017 sempatmengalamipenurunanproduksi, lihatGambar 1.

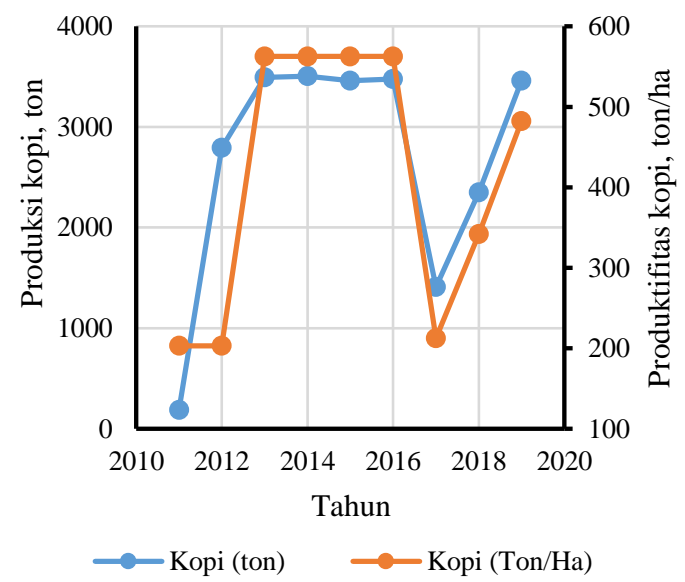

Gambar 1. Total produksi kopi darikabupatenNgadauntukperiodetahun 2011 hingga 2019. Sumber: BPS propinsi NTT, [7].

Pengembangan kopi arabika organik di Bajawa-Flores yang dikelola oleh Kelompok Tani melalui unit-unit 
pengolahan hasilseperti UPH Famasa, UPH Papataki telah menghasilkan produk kopi arabika yang mempunyai sertifikat indikasi geografis (IG) sehingga memiliki pangsa pasar kopi specialty yang sangat terbuka terutama dengan bergesernya konsumen kopi biasa ke kopi specialty di negara-negara konsumen seperti Amerika Serikat. Dinas Pertanian dan Perkebunan Provinsi NTT padaTahun 2016 menyatakan bahwa kopi arabika merupakan salah satu komoditi unggulan dari Kabupaten Ngada yang harus diupayakan pengembangannya. Pengusahaan tanaman kopi di kabupaten Ngada secara umum adalah perkebunan rakyat. Dari total areal pertanaman kopi, sebanyak 88,60 persen merupakan areal pertanaman kopi arabika dan 12,40 persen areal pertanaman kopi robusta.

Selain dijual di pasar lokal di Flores dan NTT, mayoritas kopi yang dihasilkan di Ngada dijual ke eksportir di Surabaya. Kopi Arabika Flores sangat besar peluangnya untuk tumbuh mengingat permintaan akan kopi arabika specialty sangat tinggi sementara supplynya masih terbatas. Meskipun sensitivitas kopi arabika Flores terhadap iklim mikro dan kekeringan cukup tinggi, peluang pengembangan kopi arabika tetap tinggi dan memberi manfaat ekonomis, sosial dan ekologis yang tinggi. Kopi sangat baik dalam kerangka pengelolaan sumber daya alam karena kopi ditanam dengan tanaman penaung sehingga berperan sangat positif sebagai carbon stock dan biodiversity.

\section{Gambaran Umum Lokasi Mitra}

Sejak sistem usaha pertanian menggunakan bahan kimia yang berlebihan atau revolusi hijau, telah menyebabkan lingkungan dan produksi pertanian mengalami penurunan kualitas untuk kehidupan. Semakin tinggi penggunaan pupuk dan pestisida anorganik oleh petani, menyebabkan timbulnya berbagai masalah pada alam maupun kesehatan manusia sehingga hal ini tidak dapat dibiarkan terjadi secara terus menerus karena ancaman penyakit kepada manusia akan semakin besar.

Untuk mengurangi masalah tersebut di atas dari sisi budidaya Pemerintah perlu bersikap untuk melaksanakan pertanian yang ramah lingkungan dan organik. Pertanian organik merupakan sistem budidaya pertanian dengan mengandalkan bahan-bahan alami dan dan tidak menggunakan bahan sintesis dengan tujuan menyediakan produk pertanian yang sehat buat produsen dan konsumen serta aman untuk keseimbangan lingkungan dan menjaga siklus alami[5][6].

Berangkat dari permasalahan di atas, melalui program ini secara sederhana untuk memberdayakan masyarakat dengan melakukan pelatihan kepada kelompok masyarakat petani kopi Arabika Flores Bajawa. Kelompok Tani akan dibekali keterampilan serta pengetahuan dalam mengolah memanfaatkan limbah pertanian sebagai pupuk hijau dan bokashi yang dapat digunakan pada tanaman kopi. Selain dapat digunakan sendiri pupuk tersebut, kelompok tani ini dapat mengolah pupuk tersebut dalam jumlah yang besar untuk dapat dipasarkan kepada petani di lingkungan sekitarnya. Sehingga melalui pemberdayaan masyarakat seperti ini dapat mendukung pemenuhan ketersediaan ekonomi lingkungan dalam pelestariannya.

\section{METODE PENGABDIAN}

Metode penyelesaian masalah Mitra secara lebih rinci dapat dijelaskan sebagai berikut :

\section{Tahap Persiapan dan Pembekalan}

Hal-hal yang dilakukan pada tahap persiapan ini meliputi:

- Melakukan pertemuan dengan Lurah dan menyampaikan rencana kegiatan. Dalam pertemuan ini juga, tim pelaksana akan meminta Lurah untuk mengundang tokoh masyarakat, dalam rangka penyampaian informasi yang matang dan terukur. 
- Memilih beberapa anggota Kelompok Tani yang diberikan rekomendasi oleh ketua Kelompok.

\section{Tahap Pelaksanaan}

Sosialisasi konsep dasar tentang penyedia jasa ekologi yang bernilai ekomomis melalui pembuatan pupuk hijau dan bokashi dari limbah pertanian. Hasil yang diharapkan setelah mengikuti pelatihan, peserta didik;

- Memahami konsep dan prinsip jasa ekologi yang bernilai ekomomis

- Dapat menyusun rencana tindak lanjut dalam menerapkan pola pembuatan pupuk hijau dan bokashi dari limbah pertanian

- Menjadi masyarakat yang mandiri, dan dapat menyebarluaskan informasi yang diterima kepada masyarakat lain untuk dapat melestarikan lingkungan.

- Strategi kegiatan; Paparan, diskusi,dan demonstrasi.

Dalam tahap pelaksanaan ini kegiatan yang dilakukan adalah sebagai berikut:

- Menyiapkan kelompok Tani yang mengikuti program penyuluhan dengan memberikan pembekalan-pembekalan oleh pelaksana kegiatan.

- Melakukan penyuluhan tentang bagaimana cara pembuatan pupuk kompos. Metode yang digunakan pada penyuluhan ini adalah memberikan materi-materi berupa hand out dan praktek langsung di lapangan tentang kegiatan tersebut.

- Kelompok tani bersama Tim pelaksana kegiatan melakukan pembuatan pupuk kompos.Gambar

2menunjukkankomposisi pembuatan kompos, yakni: $60 \%$ coklat, $30 \%$ hijau, dan $10 \%$ (kotoran hewan, sekam, tanah humus).

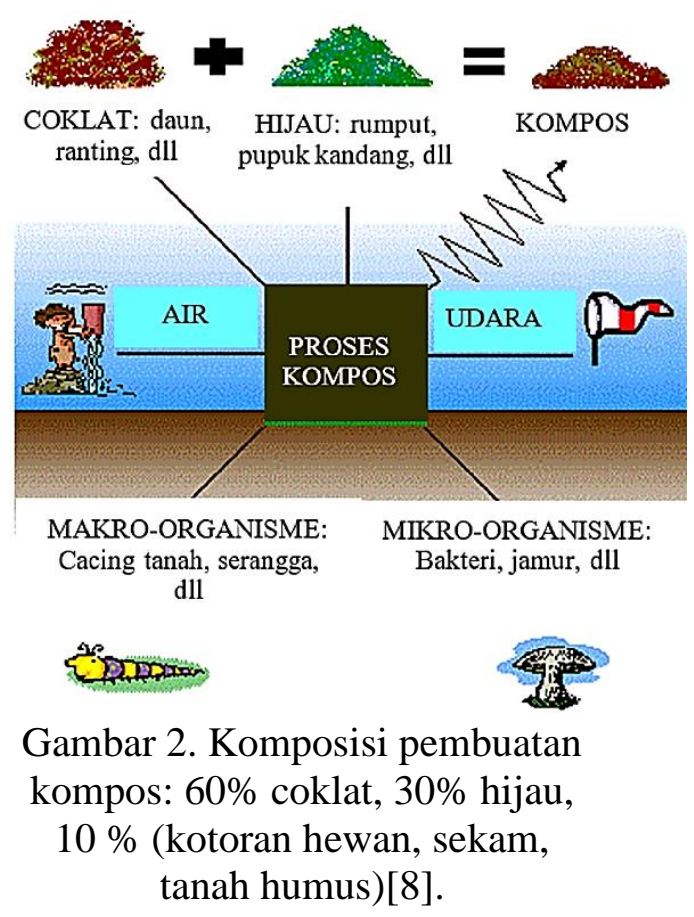

\section{Tahap Evaluasi}

- Evaluasi materi pelatihan yang telah disampaikan kepada peserta melalui tanya jawab maupun diskusi sebagai langkah pemantapan teori sebelumnya. Hal inisangatpentingdilakukanuntukmenguk urtingkatminatdanpartisipasipesertasertar encanatindaklanjutnya.[9][10].

- Membentuk kelembagaan yang disertai dengan pembinaan di tingkat masyarakat untuk mengorganisir tentang pola pengelolaan pupuk kompos yang berkelanjutan.

\section{HASIL DAN PEMBAHASAN}

\section{Proses Pembuatan Pupuk Kompos}

Proses pembuatan bokashi limbah pertanian, kotoran ternak-sekam (BKTS) sebagai pupuk organik.Persiapan, langkah kerja pembuatan BKTS,dan cara pemakaian penggunaan BKTS adalah sebagai berikut:

\section{A. Bahan-Bahan :}

Komposisibahan-bahan yang dibutuhkan dalam proses pembuatan pupuk kompos dapat dilihat pada Tabel 1 berikut: 
Tabel 1. Komposisi bahan-bahan pembuatan pupuk kompos.

\begin{tabular}{clcc}
\hline No. & \multicolumn{1}{c}{ Bahan } & Bobot & $\begin{array}{c}\text { Persen } \\
(\%)\end{array}$ \\
\hline 1 & Limbah hijauan & $20 \mathrm{~kg}$ & 20 \\
2 & Limbah coklat & $35 \mathrm{~kg}$ & 35 \\
3 & Kotoran Ternak & $10 \mathrm{~kg}$ & 10 \\
4 & Tanah humus & $15 \mathrm{~kg}$ & 15 \\
5 & Sekam bakar & $10 \mathrm{~kg}$ & 10 \\
6 & Dedak Halus & $5 \mathrm{~kg}$ & 5 \\
7 & Molase / Gula & $500 \mathrm{ml}$ & \\
8 & EM4 & $250 \mathrm{ml}$ & \\
9 & Air secukupnya & & \\
\hline
\end{tabular}

Air bersih secukupnya, tergantung dari tingkat kebasahan sekam dan kotoran ternaknya. Semua bahan setelah di campur, selanjutnya dimasukan ke dalam bak di atas tanah dengan dinding batako (ukuran $2 \mathrm{~m} \times 2 \mathrm{~m}$ x $0,5 \mathrm{~m}$ ).

B. Alat-Alat:

1. Termometer

2. Cangkul

3. Garuk

4. Ember

C. Prosedur atau cara kerja.

1. Memilih tempat bak sesuai dengan syarat-syarat yang telah ditentukan,

2. Mempersiapkan peralatan dan bahan yang dibutuhkan,

3. Semua bahan yang berukuran besar di potong-potong dalam bagian yang relative kecil, dimana semakin kecil akan semakin mudah dalam proses pengkomposan.

4. Cara pembuatan pupuk bokashi :

- Membuat larutan 1 yaitu EM 4 sebanyak $250 \mathrm{ml}+$ molase $500 \mathrm{ml}$ per 5 liter air, aduk sampai rata,

- Bahan yang terdiri dari limbah hijauan, limbah coklat, sekam bakar, kotoran ternak dan dedak dicampur secara rata.

- Bahan-bahan tersebut di atas disiram dengan larutan 1. Pencampuran dilakukan perlahan-lahan dan merata hingga Kandungan air $\pm 30-40 \%$. Kandungan air yang diinginkan diuji dengan cara menggenggam bahan. Kandungan 30-40\% ditandai dengan tidak menetesnya air bila bahan digenggam dan akan mekar bila genggaman dilepas. Bila kurang basah buat larutan serupa (Larutan 1) sampai campuran benar-benar mencapai kandungan 30-40\%.

- Meletakan campuran tersebut pada tempat yang telah dipersiapkan setinggi $15-20 \mathrm{~cm}$, tetapi dapat juga ditumpuk sampai 1,0 $\mathrm{m}$ diberi alas dan ditutup denga terpal.

- Memeriksa campuran setiap hari untuk mengetahui suhu campuran dengan termometer dan mempertahankan suhu maksimal $50^{\circ}$ C. Bila tidak ada alat termometer pemeriksaan dilakukan dengan memasukan tangan, bila suhu campuran terasa panas dan tidak tertahan maka diasumsikan suhu melebihi $50^{\circ} \mathrm{C}$, campurarn dibuka dan diaduk-aduk lalu ditutup kembali (biasanya 7 hari sekali diaduk),

- Proses frementasi ini berlangsung sekitar 4 sampai 5 minggu biasanya suhu campuran akan normal atau stabil dan ditandai dengan tumbuhnya cendawan berwarna putih,

- Setelah bahan menjadi bokashi penutup bokashi (terpal) dapat dibuka. Bokashi ini dicirikan dengan warna hitam, gembur, tidak panas, dan tidak berbau. Dalam kondisi itu pupuk bokasi sudah jadi dan siap digunakan.

- Apabila pupuk bokashi akan dijual atau dipasarkan perlu dikemas dalam kemasan yang baik supaya kelembaban pupuk tetap terjaga.

\section{Penggunaan}

Bokasi dapat digunakan seperti pupuk kandang atau pupuk kompos. Dosis yang umum digunakan yaitu:3 - 4 genggam bokashi untuk satu meter persegilahan. Penggunaan berbagai macam bokashi 
secara umum sama, namun alangkah baiknya bila penggunaannya disesuaikan dengan unsur hara dalam bokashi tersebut.

- Bokashi limbah pertanian, kotoran ternak-sekam (BKTS) sebagai pupuk organik penggunaannya sangat luas untuk tanaman baik pada masa pertumbuhan maupun proses pembuahan. Hal ini karena unsur hara yang cukup komplit.

- Bokasi jerami dan bokashi pupuk kandang baik digunakan untuk melanjutkan fermentasi penutup tanah (mulsa) dari bahan organic dan digunakan dilahan sawah karena ketersediaan bahannya cukup.

- Bokasi pupuk kandang dan bokashi pupuk kandang tanah baik digunakan untuk media pembibitan dan media tanaman yang masih kecil.

- Bokasi ekspres baik digunakan untuk penutup tanah (mulsa) pada tanaman sayur dan buah-buahan.

\section{Deskripsi Hasil Kegiatan yang Telah Dilaksanakan}

Sosialisasi berisi penyampaian materi tentang potensi dan keunggulan bahanbahan limbah pertanian sebagai pupuk organik[10][11]. Dalam kegiatan ini pula diberikan penguatan kepada masyarakat bahwa pupuk organik lebih baik pengaruhnya dibandingkan dengan pupuk sintetis, hanya saja pengaruhnya terlihat lebih lambat.

Demonstrasi pembuatan pupuk dengan bahan-bahan limbah pertanian juga diperkenalkan dan dipraktekkan langsung. Kegiatan pelatihan untuk proses pembuatan pupuk organik yang bersumber dari bahan-bahan organik yang terdapat di lingkungan sekitar. Pelatihan dilaksanakan dalam 2 hari, yaitu hari Sabtu dan Minggu, tanggal 16 dan 17 Mei 2020 yang dihadiri oleh 8 peserta yang tergabung dalam kelompok tani Sinar Tani.

Gambar 3 hingga Gambar 5 menunjukkan pembuatan pupuk kompos proses minggu kedua,proses pengadukan kompos, dan selama proses fermentasi, kompos ditutup dengan terpal. Proses pengadukan ini penting dilakukan selain untuk mempercepat proses kompos tapi juga untuk menstabilkan temperatur. Gambar 6 hasil pembuatan pupuk kompos yang dimasukan ke dalam karung siap di aplikasikan pada tanaman.

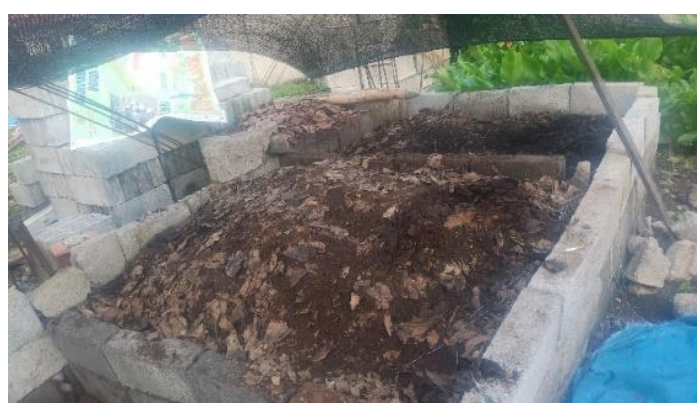

Gambar 3. Pupuk kompos proses minggu kedua.

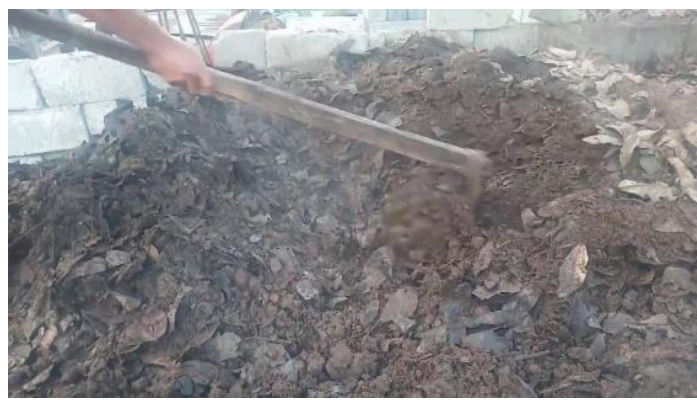

Gambar 4. Proses pengadukan kompos.

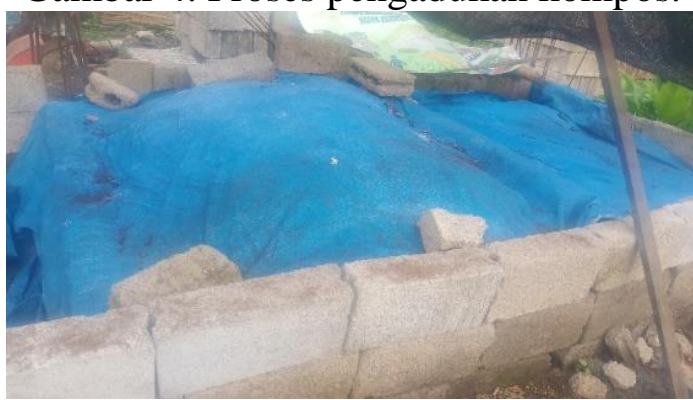

Gambar 5. Selama proses fermentasi, kompos ditutup dengan terpal.

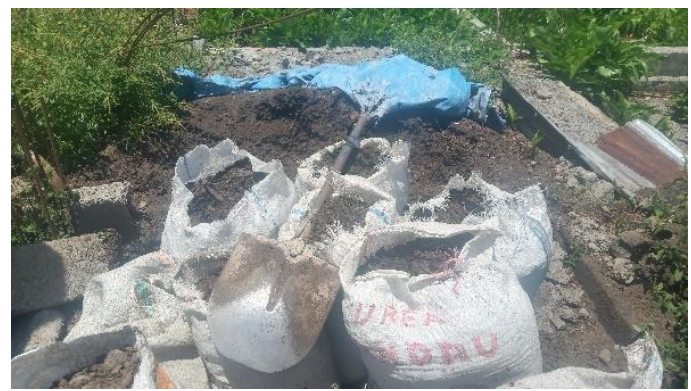




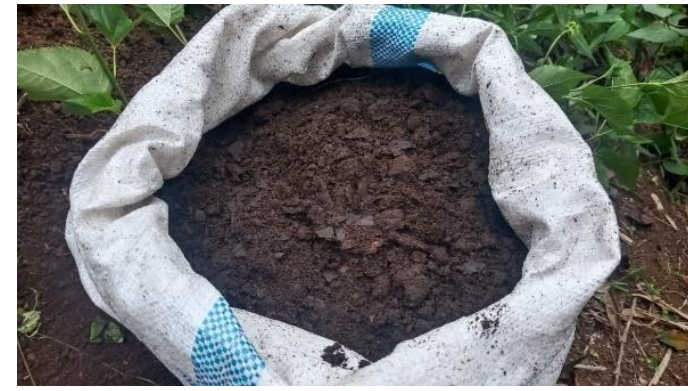

Gambar 5. Hasil pembuatan pupuk kompos, dimasukan ke dalam karung siap diaplikasikan pada tanaman.

\section{Pembahasan Hasil Pelaksanaan Kegiatan}

Kegiatan pelatihan yang telah dilaksanakan inimeliputi penyampaian materi serta demonstrasi dan praktek pembuatan pupuk kompos. Materi pelatihan meliputi dampak buruk penggunaan pupuk kimia terhadap lingkungan, keunggulandan keuntungan penggunaan pupuk organik bagi petani maupun lingkungannya. Potensi pemanfaatan limbah hasil pertanian ataupun dari lingkungan sekitar sebagai bahan baku pembuatan pupuk organik, dan tahapan pembuatan pupuk organik serta bagaimana aplikasinya pada lahan pertanian.

Kegiatan kemitraan dengan kelompok tani Sinar Tani ini berhasil memberi pemahaman kepada petani tentang konsep dan prinsip jasa ekologi yang bernilai ekomomis dari mengelola dan melestarikan lingkungan. Dapat menyusun rencana tindak lanjut dalam menerapkan pola pembuatan pupuk hijau dan bokashi dari limbah pertanian.Pemanfaatan teknologi pengolahan limbah dari produksi kopi seperti kulit kopi untuk pembuatan kompos[12][13].Menjadi masyarakat yang mandiri, dan dapat menyebarluaskan informasi yang diterima kepada masyarakat lain untuk dapat melestarikan lingkungan.
Kegiatan ini membawa dampak positif pada kelompok tani, yang ditunjukkan dengan peran aktif hampir semua peserta berminat untuk membuat pupuk organik dengan memanfaatkan limbah dari hasil pertanian mereka untuk diaplikasikan pada lahan pertaniannya masing-masing.

\section{SIMPULAN}

- Program Kemitraan Masyarakat ini telah memberikan bekal pengetahuan dan keterampilan kepada para petani untuk membuat pupuk organik ramah lingkungan dari sumberdaya hayati yang banyak terdapat di lingkungan sekitarnya.

- Program Kemitraan Masyarakat juga merupakan salah satu upaya yang sangat menunjang peningkatan kemampuan masyarakat desa dalam mengelola potensi desa yang berbudaya literat, oleh karena itu keberlanjutan program ini tetap terus dilestarikan dan dikembangkan pada setiap satuan desa agar dapat menyeluruh.

- Program Pemberdayaan Masyarakat kelurahan Kisanata, kecamatan Bajawa dalam memanfaatkan limbah pertanian seperti daun-daun, ranting-ranting kayu, dan rumput dengan komposisi $30 \%$ hijauan dan $60 \%$ bahan coklat serta $10 \%$ komponen lain untuk pembuatan pupuk kompos.

- Penggunaan pupuk sintesis secara berlebihan mengakibatkan penurunan kualitas tanah. Adapun dampak lainnya yaitu tanah menjadi miskin akan unsur hara sehingga setiap masa tanam petani harus menambah volume penggunaan pupuk sintesis, hal ini akan menambah beban petani untuk mengadakan pupuk disamping harga yang mahal, pupuk juga susah didapatkan di pasaran. Untuk menanggulangi permasalahan tersebut maka perlu adanya suatu terobosan baru pengganti pupuk sintesis. Pupuk sintesis bisa digantikan dengan pupuk 
organik padat berbahan dasar limbah petanian.

\section{UCAPAN TERIMAKASIH}

Ucapan terima kasih kepada Dekan Fakultas Sains dan Tekik Universitas Nusa Cendana atas Surat Perjanjian Pelaksanaan Pengabdian Mandiri melalui kontrak No. 1737/UN.15.15.2/PM/2020, tanggal 06 Maret 2020.

\section{DAFTAR PUSTAKA}

[1] D. A. Qodri, "Evaluasi Program Pertanian Organik Komoditas Padi, Jagung Manis, Dan Bawang Merah Di Desa Pendem Dan Dadaprejo, Kecamatan Junrejo, Kota Batu." Universitas Brawijaya, 2018.

[2] L. Fahmi, A. Rahayu, and Y. Mulyaningsih, "Pengaruh Pupuk Hayati Majemuk Cair dan Pupuk Sintetik Terhadap Pertumbuhan Tanaman Edamame (Glycine max (L.) Merr)," J. AGRONIDA, vol. 3, no. $2,2018$.

[3] A. C. Tabun, B. Ndoen, C. L. O. Leo-Penu, J. A. Jermias, T. A. Y. Foenay, and D. A. J. Ndolu, "Pemanfaatan limbah dalam produksi pupuk bokhasi dan pupuk cair organik di desa tuatuka kecamatan kupang timur," $J$. Pengabdi. Masy. Peternak., vol. 2, no. 2, 2017.

[4] E. Winarni, R. D. Ratnani, and I. Riwayati, "Pengaruh jenis pupuk organik terhadap pertumbuhan tanaman kopi," Maj. Ilm. MOMENTUM, vol. 9, no. 1, 2013.

[5] I. A. Rachman, S. Djuniwati, and K. Idris, "Pengaruh bahan organik dan pupuk NPK terhadap serapan hara dan produksi jagung di Inceptisol Ternate," J. Tanah dan Lingkung., vol. 10, no. 1, pp. 7-13, 2008.

[6] J. A. Jermias, V. D. Tome, and T. A. Foenay, "Pemanfaatan Gulma Semak Bunga Putih (Chromolaena
Odorata) Sebagai Bahan Pembuat Pupuk Organik Bokhasi Dalam Rangka Mengatasi Penyempitan Padang Pemggembalaan Dan Menciptakan Pertanian Terpadu Berbasis Organik," J. Pengabdi. Masy. Peternak., vol. 1, no. 1, 2016.

[7] "Badan Pusat Statistik Provinsi Nusa Tenggara Timur," 2019. https://ntt.bps.go.id/subject/54/perk ebunan.html\#subjekViewTab3.

[8] S. Zafar, "Introduction to Composting," EcoMENA Echoing Sustain. MENA.[Online] Available https//www. ecomena. org/composting/[Accessed 19 August 2018], 2015.

[9] A. A. Suhastyo, "Pemberdayaan masyarakat melalui pelatihan pembuatan pupuk kompos," JPPM (Jurnal Pengabdi. dan Pemberdaya. Masyarakat), vol. 1, no. 2, pp. 63-68, 2017.

[10] S. Suherman, N. Nurhapsa, and I. Irmayani, "Pemberdayaan Masyarakat Tani Di Desa Batu Mila Melalui Pelatihan Pembuatan Pupuk Organik Dari Limbah Pertanian," in Prosiding Seminar Nasional Sinergitas Multidisiplin Ilmu Pengetahuan dan Teknologi, 2018, vol. 1, pp. 119-124.

[11] H. Wijayanto, D. Riyanto, B. Triyono, and H. P. W. Estu, "Pemberdayaan Kelompok Tani Desa Jatimalang, Kabupaten Pacitan melalui Pelatihan Pembuatan Pupuk Organik," Agrokreatif J. Ilm. Pengabdi. Kpd. Masy., vol. 5, no. 2, pp. 109-114, 2019.

[12] D. Maulida, L. Erfa, F. Ferziana, and Y. Yusanto, "Teknologi Pemanfaatan Limbah Kulit Kopi Melalui Pelatihan Pembuatan Kompos," 2018.

[13] D. A. Arisandy, L. Fitriani, and M. Luthfiana, "Pengolahan Limbah Kulit Buah Kopi Sebagai Pupuk 
Organik Di Desa Sumber Bening," KOMMAS J. Pengabdi. Kpd. Masy., vol. 1, no. 1, 2020. 